\title{
The Accuracy of the Altman, Ohlson, Springate and Zmejewski Models in Bankruptcy Predicting Trade Sector Companies in Indonesia
}

\author{
Sri Elviani ${ }^{1}$, Ramadona Simbolon ${ }^{1}$, Zenni Riana ${ }^{1}$, Farida Khairani ${ }^{1}$, Sri Puspa \\ Dewi $^{2}$, Fauzi $^{3}$ \\ ${ }^{1}$ Faculty of Economy, Accounting Study Program, Universitas Islam Sumatera Utara, Medan, Indonesia \\ ${ }^{2}$ Faculty of Economy, Accounting Study Program, Universitas Al-Azhar, Medan, Indonesia \\ ${ }^{3}$ Faculty of Economy, Management Study Program, Universitas Islam Sumatera Utara, Medan, Indonesia
}

\begin{abstract}
Bankruptcy prediction models continue to develop both in terms of forms, models, formulas, and analysis systems. Various bankruptcy prediction studies currently conducted aim to find the most appropriate and accurate bankruptcy prediction model to be used in predicting bankruptcy. This study aims to determine the most appropriate and accurate model in predicting the bankruptcy of 53 trade sector companies in Indonesia. The analysis technique used in this study is binary logistic regression. The results of this study prove that the most appropriate and accurate model in predicting bankruptcy of trade sector companies in Indonesia is the Springate model and the Altman model.
\end{abstract}

Keywords

Bankruptcy; Altman;

Ohlson; Springate;

Zmijewski

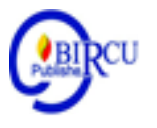

\section{Introduction}

Bankruptcy can be interpreted as a failure of the company in carrying out the company's operations to generate profits characterized by the occurrence of severe financial difficulties that the company is unable to run the company's operations properly. Bankruptcy prediction is an important topic in the business world. A timely prediction is valuable for companies to evaluate risks or prevent bankruptcy. Research on bankruptcy prediction was first conducted by (Beaver, 1966), and subsequently conducted by (Altman, 1968) resulted in a bankruptcy prediction model known as the Altman Z score model. Research conducted by Beaver and Altman was motivated by many companies that went bankrupt in the 1960s in the United States. After the 1970s the model for predicting bankruptcy continued to develop both in terms of model shapes, formulas, analysis systems, and samples such as Springate Model, Probit Zmijewski Model, Ohlson logit model, Fulmer Model, Grover Model, Shumway Hazard model. In predicting bankruptcy, these models have different levels of accuracy based on the measurements used.

Various bankruptcy prediction studies currently carried out aim to find the most appropriate and accurate bankruptcy prediction model to be used as a prediction tool, such as; (Xu and Zhang, 2009) predict bankruptcy using the Altman and Ohlson models. They found that the steps in the traditional Altman and Ohlson models were also beneficial individually for the Japanese market. Xu and Zhang built a new measure combining bank dependency and Keiretsu dependence. This new step further enhances the ability to predict the bankruptcy of companies registered in Japan.

(Wu, Gaunt and Gray, 2010) examined the empirical performance of a number of bankruptcy prediction models using a variety of different independent variables such as the MDA Altman model, the Ohlson logit model, the Zmijewski probit model and the Shumway Hazard model. The test results show that a comprehensive model covering key accounting 
information, market data, and company characteristics significantly outperforms the model from the existing literature. The results show the Altman MDA model has poor performance compared to other models in the literature. Ohlson's logit model and Zmijewski's probit performed quite well during the 1970s but their performance has deteriorated during more recent periods. Hazard Shumway's model, which includes market data and company characteristics, generally outperforms a model that is only based on accounting information. Wu concluded that a more comprehensive model that draws conclusions from key accounting information, market data, and company characteristics provides the most reliable estimates for future bankruptcy. This is in line with various types of data capturing various aspects of a company's financial difficulties.

(Marcinkevicius and Kanapickiene, 2014) predict the bankruptcy of construction companies in Lithuania by using 5 bankruptcy prediction models: the Altman, Springate, Taffler and Tisshaw, Chesser, and Zavgren models. The results showed that the most accurate bankruptcy prediction model with the highest probability of bankruptcy was the Springate model and the Chesser model. (Timmermans and Finance, 2014) in his research used three bankruptcy prediction model: the Altman, Ohlson and Zmijewski models. The results showed that when the original model of Altman, Ohlson and Zmijewski was applied to a more recent sample in the 2005-2007 period, the predictive power of the model was low and bankruptcy was overpredicted. In order for the original model to be used in the new period especially after BACPA's change in bankruptcy law in 2005, the model must be recalibrated. After recalibration of the models, the accuracy of all models increases, especially applying the recalibrated model of Altman and Ohlson in the 2005- 2007 sample resulting in a percentage of observations that are correct and of a high area under the Receiver's Operation Curve.

(Pongsatat, Ramage and Lawrence, 2004) predicted the company's bankruptcy by testing the comparative ability of Ohlson's Logit model and the Altman four variant models. Testing was carried out on 60 companies that went bankrupt and 60 companies that did not go bankrupt during 1998 to 2003 . This study showed that each of the two methods had predictive ability when applied to Thai companies and there were no significant differences in the predictive ability of each company in Thailand, (Aminian, Mosazade and Khoshkho, 2016). This study compares the ability of the Altman, Springate, Zmijewski and Grover models to predict the bankruptcy of 35 textile and ceramics companies listed on Tehran Stock Exchange during the 2008 to 2013 period. The results show that during the five years of each Grover's research period, Altman, Springate and Zmijewski have a better ability to predict the financial crisis / bankruptcy of 35 textile and ceramics companies listed on Tehran stock exchange.

(Ashraf, Elisabete and Serrasqueiro, 2019), the results of the study showed that the five bankruptcy prediction models were applied to the Pakistan equity market, but the accuracy of the prediction of the whole model decreased over time. The D-score model of Blums, logit model of Ohlson, and hazard model of Shumway showed lower predictive results than the Zscore model of Altman and Probit model of Zmijewski. And for the accuracy of the overall model predictions it was found that, the Zmijewski probit model more accurately predicted the company's bankruptcy than the other four models during the study time period, where the prediction of the $\mathrm{Z}$ score was the best for the company at the initial and advanced stage of distress, with minimum Type I errors $22.6 \%$. If a Type I error is considered more expensive, then the Z-scor model is more ideal than the probit model.

(Nurcahyanti, 2015) conducted an examination over 46 companies listed on the Indonesian Stock Exchange in the 2010 to 2013 observation period using post hoc and error 
types. The results showed that there were significant differences between the results of the bankruptcy analysis of the Altman Z-score model, Springate and Zmijewski models. The most accurate model based on the post hoc test was the Altmant Z-score model while the most accurate model based on the type of error was the Zmijewski model. (Syamni, Majid and Siregar, 2018) explored empirically the use of Ohlson, Altman Modification, Grover, Springate, and Zmijewski models in predicting the bankruptcy of 19 coal mining companies, and their impact on stock prices. The results proved that the Ohlson prediction model and Altman modification predominantly affected the stock price of coal companies in Indonesia. This indicates that the bankruptcy prediction model can be used to predict stock price movements and financial performance of the coal industry in Indonesia.

However, the various results of research conducted have not been able to find a model that is most appropriate and accurate among other bankruptcy prediction models. Bankruptcy prediction research in Indonesia is still limited to the application of bankruptcy prediction models found abroad, whether the bankruptcy prediction model can be applied as an appropriate prediction tool for companies in Indonesia or not. Bankruptcy prediction research in Indonesia needs to be further developed to find the most suitable model to be applied to Indonesian companies. This is important because the financial characteristics of Indonesian companies are different from those of the foreign companies, which are influenced by economic, legal, political, and government regulations in each country. The difference in characteristics naturally causes differences in the standard values or the size of the research variables used. Therefore it needs to be further investigated whether the prediction model used abroad is appropriate to be used as a prediction tool for company bankruptcy in Indonesia, and which model or formula is the most accurate in predicting bankruptcy of companies in Indonesia, according to the type and characteristics of the company.

\section{Review of Literature}

\subsection{Altman Models}

(Altman, 1968) stated that most bankruptcy prediction models at the time used univariate analysis. But in reality the results of the univariate method are often interpreted incorrectly (such as traditional ratio analysis), so Altman decided to use a different method namely the Multiple Discriminant Analysis (MDA) technique. The MDA technique is used for situations where two groups are identified and the dependent variable can only take two values. In this example, the dependent variable is bankrupt or not bankrupt. MDA creates a linear combination that can distinguish different groups, using all variables simultaneously, which is different from traditional ratio analysis where the effects of each variable are measured separately. (Altman, 1968) used 66 samples, which were divided into 2 groups. The first group, 33 companies with bankrupt conditions consisting of US manufacturers filing for bankruptcy between 1946-1965 which had an SIC code between 2000 and 3999. The average size of the company's assets was 6.4 million USD, ranging from 0.7 and 25.9 million USD. Altman acknowledged that this group was not homogeneous with respect to size and industry, even though all companies were relatively small and from the manufacturing industry. The second group, 33 samples of non-bankrupt companies, consisted of paired samples from manufacturing companies selected based on random stratification. These companies are grouped by industry and size, with a range of asset sizes limited to USD 1-25 million.

Altman eliminated small companies (less than 1 million US dollars in total assets) due to lack of data and very large companies due to the scarcity of bankruptcies among these 
companies in that period, and therefore, companies in group 2 were slightly larger than group 1. Data collected for companies in both groups were from the same year. For group 1, the data were from the financial statements one reporting period before bankruptcy. Using financial statements, Altman compiled a list of 22 financial ratios potentially important to evaluate. He classified these variables into five standard ratio categories: liquidity, profitability, leverage, solvency, and activity. This ratio was chosen based on their popularity in literature and their potential relevance for this study. The last discriminant function was estimated by (Altman, 1968) as the following:

$$
\mathrm{Z}=0.012 \mathrm{X} 1+0.014 \mathrm{X} 2+0.033 \mathrm{X} 3+0.006 \mathrm{X} 4+0.999 \times 5
$$

Where:

$\mathrm{Z}=$ Overall Index (Altman Z-score) X1 = Working Capital to total assets X2 = Retained Earnings to Total Assets

X3 = Earnings Before Income Tax (EBIT) to Total Assets X4 = Market Value of Equity to Book Value

X5 $=$ Sales to Total Assets

The discriminant function classifies $95 \%$ correct in one year before bankruptcy, and $83 \%$ two years before bankruptcy. This function is also applied to a sample of bankrupt companies, three, four and five years before bankruptcy and predicts $48 \%, 29 \%$ and $36 \%$, respectively. Because the power of prediction dropped drastically after the second year, Altman concluded that the model could not be relied upon to predict for more than two years earlier. Companies with a Z-score $\geq 2,675$ are not expected to go bankrupt, and companies with a Z-score $<2,675$ are not expected to go bankrupt. Altman also introduced gray areas, to make classification more accurate. In this case, Altman cannot be recommended for companies with a $\mathrm{Z}$ score between 1.81 and 2.99, but companies with a $\mathrm{Z}$ score lower than 1.81 are predicted to go bankrupt, and companies with a $\mathrm{Z}$ score higher than 2.99 do not go bankrupt.

The original Z-Score model (1968) is based on the market value of the company and thus only applies to publicly traded companies. (Altman, 1984) emphasized that the Z-Score model (1968) was aimed at publicly traded companies and that ad hoc adjustments were not scientifically valid. (Altman, 1984) advocates a complete re-estimation of the model, replacing the book value of equity for market value at X4. Using the same data, Altman extracted the following revised $\mathrm{Z}$ - Score model:

$$
\mathrm{Z}=0.717 \mathrm{X} 1+0.847 \mathrm{X} 2+3.107 \mathrm{X} 3+0.420 \mathrm{X} 4+0.998 \mathrm{X} 5
$$

where X4 = Book value of equity / Book value of total liabilities, with other variables equal to those in the original Z-Score model (1968). Due to the lack of a private company database, Altman did not test the Z-Score model on a secondary sample. However, he analyzed the accuracy of a four-variable Z "model that excludes the Sales / Total asset ratio (X5), from the revised model because potential industry effects are more likely to occur when such industries - sensitive variables (asset turnover) are included in the model. Altman then estimates the following four Z "- Score variable models (Altman, 1984):

$$
\mathrm{Z}=3.25+6.56 \mathrm{X} 1+3.26 \mathrm{X} 2+6.72 \mathrm{X} 3+1.05 \mathrm{X} 4
$$

The EBIT / Total asset ratio, (X3), contributes most to the power of discrimination in this version of the model. The classification results for the $Z$ "-Score model are identical to the revised five- variable Z'-Score model. In the current study, empirical analysis focuses on the performance of the Z" -Score version of the model in predicting bankruptcy, where it has the widest scope, because it is aimed at for privately owned and public companies and for manufacturing and non- manufacturing. 


\subsection{Zmijewski}

(Zmijewski, 1984) uses the probit method to predict bankruptcy. Empirical tests are conducted on financial distress models that require a sample of companies that are experiencing financial pressure and companies that are not experiencing financial pressure. Zmijewski took a research population consisting of all companies listed on the American and New York Stock Exchanges during the 1972 to 1978 period that had an industry code (SIC) of less than 6000. The number of companies in the population ranged from 2,082 to 2,241 per year. Samples of bankrupt companies with complete data of 81 companies were collected over the years. For consistency, one year (1972 to 1978) was assigned randomly to each company that was not bankrupt with complete data, and companies that were not bankrupt were also collected throughout the year. This resulted in a sample of 1,600 companies which did not go bankrupt so that a total sample of 1,681 companies (81 bankrupt companies and 1,600 companies did not go bankrupt).

Zmijewski divides a total of 1,681 sample companies into two random sections, the first part is called the "estimation sample" which contains 40 bankrupt companies and 800 that are not bankrupt, and the second part is called the "prediction sample" which contains 41 bankrupt and 800 companies that are not bankrupt. The estimation sample is used to select customer-based alternative estimation sub-estimates; Predictive samples are used to compare WESML and un- weighted assessments on the basis of predicted probabilities. Each choicebased sample has a different composition (eg, the frequency of bankrupt companies), making comparison of classifications between samples difficult; However, the prediction sample is identical in all estimates and is a good benchmark for comparison. Companies with a probability of greater than 0.5 are classified as bankrupt, and companies with a probability less than 0.5 are classified as bankrupt. The overall out-of-sample accuracy rate of the Zmijewski model is $95.29 \%$.

\subsection{Ohlson}

The MDA approach has become the most popular technique for predicting bankruptcy using vector predictors. (Ohlson, 1980) states that there are problems when using the MDA methodology, among the problems that arise include: (i) There are certain statistical requirements imposed on the nature of the predictor distribution, such as variance-covariance predictors which must be the same for both groups (bankrupt companies and non-bankrupt companies); (ii) The output of the application of the MDA model is a score that has little intuitive interpretation, because it is basically an ordinal (discriminatory) ranking; (iii) there are certain problems related to the "matching" procedure (bankrupt companies and nonbankrupt companies are matched according to criteria such as industry size.

(Ohlson, 1980) uses the econometric methodology from conditional logit analysis to predict company bankruptcy. The use of conditional logit analysis basically avoids the problems inherent in the MDA approach. The data used includes public industry companies from 1970 to 1976. Ohlson observed 105 bankrupt companies and 2,058 non-bankrupt companies. Data for bankrupt companies did not come from Moody's Manual, instead the data were obtained from 10- K financial reports as reported at the time. This procedure has one important advantage: the report shows at what point they are released to the public, and therefore one can check whether the company goes bankrupt before or after the release date. 105 bankrupt companies and 2058 non-bankrupt companies were used to build three models; the first model predicted bankruptcy in one year, the second model predicted bankruptcy of companies that were not bankrupt in the first year, but went bankrupt in the second year. The 
third model predicted bankruptcy in one or two years. Ohlson uses a model consisting of 9 different predictors.

The logit model is relatively simple and the results are easily interpreted, because this is a probability, which is a number between 0 and 1 . In the logistic model, it is assumed that errors are logically distributed standards. The percentage of observations that are predicted correctly from the first model was $96.12 \%$, but this number must be interpreted with caution. when the model predicts bankruptcy in all cases, the percentage that is classified correctly is $2058 /(2058+105)=95.15 \%$. To obtain a more useful level of accuracy, Ohlson plots type I and type II errors, and finds that the optimal cut-off point, which minimizes the percentage of type I and type II errors, is 0.038. This means that in the model, a company with a probability of less than 0.038 is predicted not to go bankrupt and a company with a probability higher than 0.038 is predicted to go bankrupt. When using a 0.038 cutoff point, Ohlson's first model classifies $87.6 \%$ of companies that went bankrupt and $82.6 \%$ of companies that did not go bankrupt properly at $\mathrm{t}-1$.

\subsection{Springate}

(Springate, 1978) produced a bankruptcy prediction model that was created by following the procedure of the Altman model which was built in the United States. The Springate model uses step-wise multiple discriminate analysis to choose the 4 best ratios out of the 19 most commonly used financial ratios. These 4 ratios are the best ratios that distinguish between failed and non- failing companies. The sample used by Springate is 40 companies located in Canada.

The cutoff value applied to this model is 0.862 ; if the resulting bankruptcy prediction result is $<0.862$ then the company is in bankrupt condition and vice versa, if the resulting bankruptcy prediction result is> 0.862 then the company is in non-bankrupt condition. This model has an accuracy rate of $92.5 \%$ in tests conducted by Springate.

\section{Research Method}

The populations of this study are trading sector companies listed on the Indonesia Stock Exchange (IDX) during the observation period 2012 to 2017 and accessed through the website www.idx.co.id. The research data were selected using a purposive sampling technique. Samples obtained during the observation period of the trade sector were listed on the Indonesian stock exchange, resulted in 52 non-bankrupt companies and 1 bankrupt company or did not have business continuity. To predict company bankruptcy, this study uses Altman, Ohlson, Springate, and Zmijewski's bankruptcy prediction models. Statistical techniques, formulas, descriptions, and score categorization used for each bankruptcy prediction model are presented in Table 1.

The fourth score of the bankruptcy prediction model investigated is then treated as an independent variable to see which bankruptcy prediction model is the most accurate in determining the bankruptcy of a company of the four prediction models used in this study. The analytical method used is binary logistic regression analysis. Regression models formed in this study are based on logistic regression analysis:

Where:

$$
\mathrm{Y}=\alpha+\beta 1 \mathrm{X} 1+\beta 1 \mathrm{X} 1+\beta 1 \mathrm{X} 1+\beta 1 \mathrm{X} 1+\mathrm{e}
$$

$\alpha=$ constant

$\beta=$ regression coefficient $\mathrm{Y}=$ Bankrupt Not Bankrupt $\mathrm{X} 1=$ Altman Score 
$\mathrm{X} 2=$ Ohlson Score X3 = Springate Score

$\mathrm{X} 4=$ Zmejewski Score

Table 1. The Bankruptcy Prediction Models

\begin{tabular}{|c|c|c|c|c|c|}
\hline No & Model & $\begin{array}{l}\text { Statistical } \\
\text { Technique }\end{array}$ & Formulation & Description & $\begin{array}{l}\text { Score } \\
\text { category }\end{array}$ \\
\hline \multirow[t]{11}{*}{1} & Altman & MDA & $\begin{array}{l}\mathrm{AZ}=6.56 \mathrm{X}_{1}+3.26 \mathrm{X}_{2} \\
+6.72 \mathrm{X}_{3}+1.05 \mathrm{X}_{4}\end{array}$ & $\mathrm{AZ}=$ Altman Z-Score & \\
\hline & Z-score & & & $\mathrm{X}_{1}=$ Working & $\mathrm{Z}<=$ \\
\hline & & & & Capital/Total Assets & 1.10bankrupt \\
\hline & (1983) & & & $\mathrm{X}_{2}=$ Retained & $\mathrm{Z}=$ = grey \\
\hline & & & & Earnings/Total Assets & 1.10 area \\
\hline & & & & & \\
\hline & & & & & 2.60 \\
\hline & & & & $\mathrm{X}_{3}=\mathrm{EBIT} /$ Total Assets & $Z>=$ not \\
\hline & & & & & 2.60 bankrupt \\
\hline & & & & $X_{4}=B V$ of & \\
\hline & & & & Equity/Total Liabilities & \\
\hline \multirow[t]{24}{*}{2} & Ohlson & Logit & $\mathrm{OS}=-1.32-0.41 \mathrm{X}_{1}+$ & OS = Ohlson Score & \\
\hline & & & $6.03 X_{2}-1.439 X_{3}+$ & & $>$ bankrupt \\
\hline & & & $0.08 \mathrm{X}_{4}$ & & 0.38 \\
\hline & Score & & $-2.37 X_{5}-1.83 X_{6}+$ & $\mathrm{X}_{1}=\log (\mathrm{TA} / \mathrm{GNP}-$ & OS = grey \\
\hline & & & $0.285 \mathrm{X}_{7}-1.72 \mathrm{X}_{8}-$ & Price Index) & $=$ area \\
\hline & & & $0.52 \mathrm{X}_{9}$ & & 0.38 \\
\hline & (1980) & & & $\mathrm{X}_{2}=$ Total & $\mathrm{OS}=$ not \\
\hline & & & & Liabilities/Total Assets & $<$ bankrupt \\
\hline & & & & & 0.38 \\
\hline & & & & $\mathrm{X}_{3}=$ Working & \\
\hline & & & & Capital/Total Assets & \\
\hline & & & & $\mathrm{X}_{4}=$ Current & \\
\hline & & & & Liabilities/Current & \\
\hline & & & & Assets & \\
\hline & & & & $\mathrm{X}_{5}=\mathrm{OENEG}^{\mathrm{a}}$ & \\
\hline & & & & $\mathrm{X}_{6}=$ Net Income $/$ Total & \\
\hline & & & & Assets & \\
\hline & & & & $X_{7}=$ & \\
\hline & & & & Operations & \\
\hline & & & & Funds/Total & \\
\hline & & & & Liabilities & \\
\hline & & & & $\mathrm{X}_{8}=\mathrm{INTWO}^{\mathrm{b}}$ & \\
\hline & & & & $\mathrm{X}_{9}=$ Change in Net & \\
\hline & & & & Income & \\
\hline \multirow[t]{3}{*}{3} & Springate & Step-Wise & $\mathrm{SS}=1.03 \mathrm{X}_{1}+3.07 \mathrm{X}_{2}$ & $\mathrm{SS}=$ Springate Score & $\mathrm{SS}=$ not \\
\hline & & & $+0.66 X_{3}+0.4 X_{4}$ & & $>$ bankrupt \\
\hline & & & & & 0.86 \\
\hline
\end{tabular}




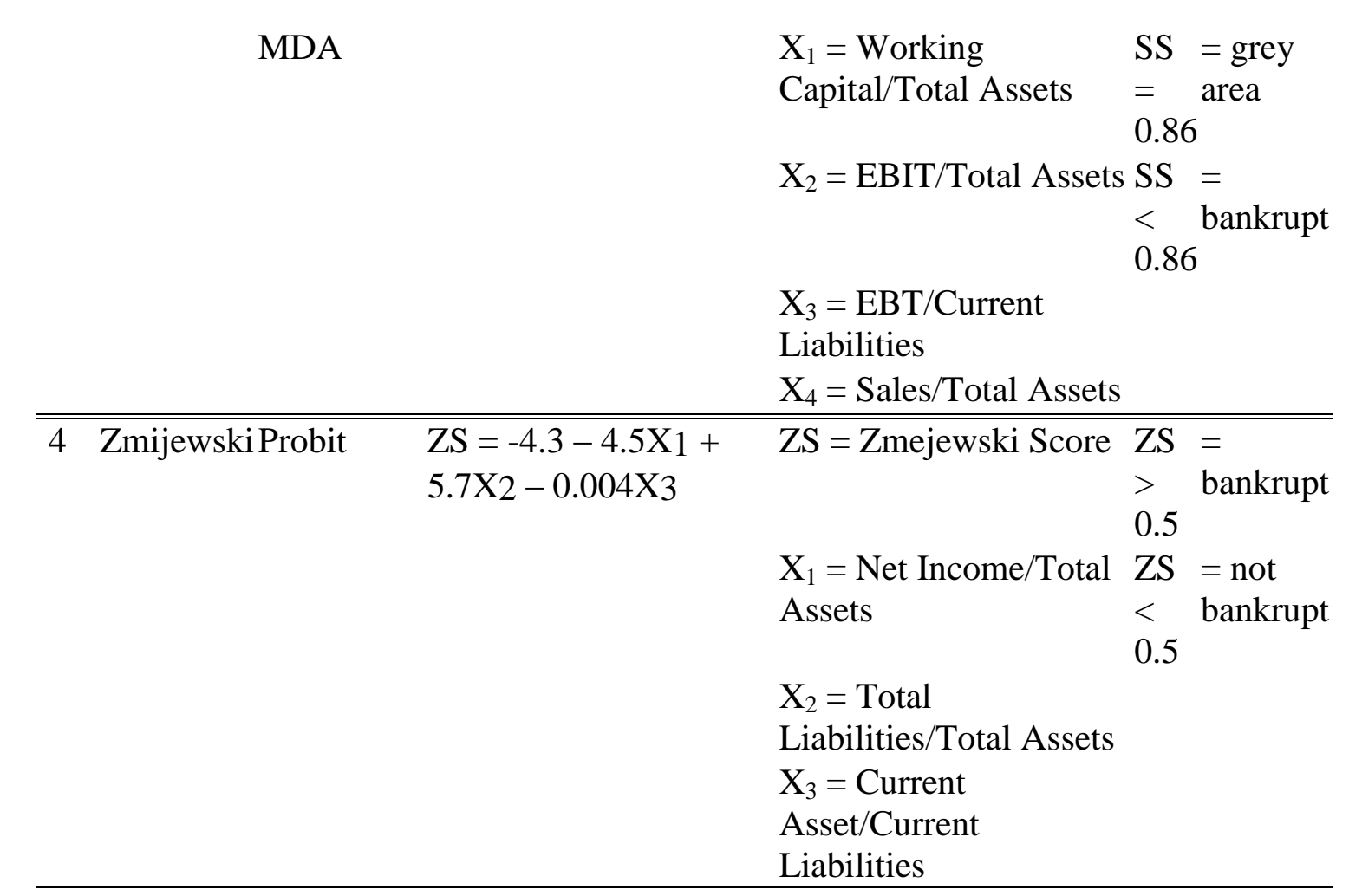

\section{Discussion}

The results of calculations and predictions for each bankruptcy prediction model are presented in Table 2 below:

\begin{tabular}{|c|c|c|c|c|c|c|c|c|c|}
\hline \multirow[b]{2}{*}{ No } & \multirow[b]{2}{*}{ PT } & \multicolumn{2}{|l|}{ Altman } & \multicolumn{2}{|l|}{ Ohlson } & \multicolumn{2}{|l|}{ Springate } & \multicolumn{2}{|l|}{ Zmijewski } \\
\hline & & Score & Predict. & Score & Predict. & Score & Predict. & Score & Predict. \\
\hline 1 & ACES & 4.01 & $\mathrm{H}$ & -6.13 & $\mathrm{H}$ & 2.72 & $\mathrm{H}$ & -88.47 & $\mathrm{H}$ \\
\hline 2 & AIMS & 28.49 & $\mathrm{H}$ & -1.14 & $\mathrm{H}$ & -4.42 & B & 87.67 & B \\
\hline 3 & AKRA & 1.59 & G & -3.17 & $\mathrm{H}$ & 0.74 & B & -31.26 & $\mathrm{H}$ \\
\hline 4 & AMRT & 0.91 & B & -0.49 & $\mathrm{H}$ & 1.39 & $\mathrm{H}$ & -12.93 & $\mathrm{H}$ \\
\hline 5 & APII & 2.08 & G & -4.09 & $\mathrm{H}$ & 0.55 & B & -19.45 & $\mathrm{H}$ \\
\hline 6 & BMSR & 0.06 & B & -5.08 & $\mathrm{H}$ & 1.89 & $\mathrm{H}$ & 17.38 & B \\
\hline 7 & CENT & 3.50 & $\mathrm{H}$ & -7.08 & $\mathrm{H}$ & -0.14 & B & 7.11 & B \\
\hline 8 & CLPI & 3.53 & $\mathrm{H}$ & -5.26 & $\mathrm{H}$ & 1.37 & $\mathrm{H}$ & -53.09 & $\mathrm{H}$ \\
\hline 9 & CMPP & -0.45 & B & -2.55 & $\mathrm{H}$ & 0.40 & B & -1.92 & $\mathrm{H}$ \\
\hline 10 & CNKO & -0.57 & B & -3.97 & $\mathrm{H}$ & 0.16 & B & 53.97 & B \\
\hline 11 & CSAP & 0.64 & B & -1.96 & $\mathrm{H}$ & 0.83 & B & -8.42 & $\mathrm{H}$ \\
\hline 12 & DSSA & 1.30 & G & -3.01 & $\mathrm{H}$ & 0.58 & B & -1.97 & $\mathrm{H}$ \\
\hline 13 & ECII & 1.06 & B & 37.96 & B & 0.06 & B & 3.82 & B \\
\hline 14 & EPMT & 2.63 & $\mathrm{H}$ & -5.16 & $\mathrm{H}$ & 1.57 & $\mathrm{H}$ & -37.65 & $\mathrm{H}$ \\
\hline 15 & ERAA & 1.50 & G & -3.85 & $\mathrm{H}$ & 1.39 & $\mathrm{H}$ & -17.11 & $\mathrm{H}$ \\
\hline 16 & FISH & 1.70 & G & -1.49 & $\mathrm{H}$ & 1.88 & $\mathrm{H}$ & -36.43 & $\mathrm{H}$ \\
\hline 17 & GLOB & 1.51 & G & -2.44 & $\mathrm{H}$ & 0.55 & B & 710.84 & B \\
\hline
\end{tabular}




\begin{tabular}{|c|c|c|c|c|c|c|c|c|c|}
\hline 18 & GOLD & 0.77 & B & -5.53 & $\mathrm{H}$ & -0.17 & B & 2.09 & B \\
\hline 19 & HERO & 1.06 & B & -3.99 & $\mathrm{H}$ & 0.78 & B & -10.01 & $\mathrm{H}$ \\
\hline 20 & HEXA & 2.43 & G & -3.01 & $\mathrm{H}$ & 0.99 & $\mathrm{H}$ & -22.88 & $\mathrm{H}$ \\
\hline 21 & INTA & -0.32 & $\mathrm{H}$ & -0.65 & $\mathrm{H}$ & -0.03 & B & 22.13 & B \\
\hline 22 & INTD & 7.30 & $\mathrm{H}$ & -4.40 & $\mathrm{H}$ & 2.07 & $\mathrm{H}$ & -14.73 & $\mathrm{H}$ \\
\hline 23 & ITTG & 19.73 & $\mathrm{H}$ & -3.54 & $\mathrm{H}$ & -1.10 & B & 19.59 & B \\
\hline 24 & JKON & 1.93 & G & -4.47 & $\mathrm{H}$ & 0.97 & $\mathrm{H}$ & -39.00 & $\mathrm{H}$ \\
\hline 25 & KOBX & 0.02 & B & -2.63 & $\mathrm{H}$ & -0.01 & B & 30.19 & B \\
\hline 26 & KOIN & 0.26 & B & -1.19 & $\mathrm{H}$ & 0.82 & B & 0.42 & $\mathrm{H}$ \\
\hline 27 & KONI & -0.70 & B & -2.97 & $\mathrm{H}$ & 0.24 & B & 27.42 & B \\
\hline 28 & LPPF & 7.02 & $\mathrm{H}$ & -1.42 & $\mathrm{H}$ & 3.06 & $\mathrm{H}$ & -187.85 & $\mathrm{H}$ \\
\hline 29 & LTLS & 0.98 & B & -0.66 & $\mathrm{H}$ & 0.68 & B & -9.48 & $\mathrm{H}$ \\
\hline 30 & MAPI & 1.26 & G & -2.13 & $\mathrm{H}$ & 0.85 & $\mathrm{H}$ & -9.09 & $\mathrm{H}$ \\
\hline 31 & MDRN & 2.15 & G & -4.22 & $\mathrm{H}$ & 0.80 & B & 144.71 & B \\
\hline 32 & MICE & 1.82 & G & -4.98 & $\mathrm{H}$ & 0.66 & B & -15.52 & $\mathrm{H}$ \\
\hline 33 & MIDI & 1.15 & G & 0.11 & $\mathrm{H}$ & 1.18 & $\mathrm{H}$ & -20.50 & $\mathrm{H}$ \\
\hline 34 & MPMX & 1.03 & B & -1.17 & $\mathrm{H}$ & 0.74 & B & -13.14 & $\mathrm{H}$ \\
\hline 35 & MPPA & 0.92 & B & -0.42 & $\mathrm{H}$ & 0.91 & $\mathrm{H}$ & -3.24 & $\mathrm{H}$ \\
\hline 36 & OKAS & -0.46 & B & -0.86 & $\mathrm{H}$ & 0.15 & B & 37.92 & B \\
\hline 37 & RALS & 2.82 & $\mathrm{H}$ & -2.97 & $\mathrm{H}$ & 1.05 & $\mathrm{H}$ & -42.26 & $\mathrm{H}$ \\
\hline 38 & RANC & 1.42 & G & -7.63 & $\mathrm{H}$ & 1.35 & $\mathrm{H}$ & -26.67 & $\mathrm{H}$ \\
\hline 39 & RIMO & -16.37 & B & 14.13 & B & -0.33 & B & 53.32 & B \\
\hline 40 & SDPC & 0.88 & B & -1.88 & $\mathrm{H}$ & 1.29 & $\mathrm{H}$ & -6.51 & $\mathrm{H}$ \\
\hline 41 & SKYB & 42.31 & $\mathrm{H}$ & -7.86 & $\mathrm{H}$ & 26.81 & $\mathrm{H}$ & -507.99 & $\mathrm{H}$ \\
\hline 42 & SONA & 1.32 & G & -2.88 & $\mathrm{H}$ & 0.54 & B & 4.50 & B \\
\hline 43 & SQMI & -57.81 & B & 14.96 & B & 8.58 & $\mathrm{H}$ & -470.50 & $\mathrm{H}$ \\
\hline 44 & TELE & 1.58 & G & -1.27 & $\mathrm{H}$ & 2.04 & $\mathrm{H}$ & -26.54 & $\mathrm{H}$ \\
\hline 45 & TGKA & 1.84 & G & -3.14 & $\mathrm{H}$ & 1.89 & $\mathrm{H}$ & -35.98 & $\mathrm{H}$ \\
\hline 46 & TIRA & 0.75 & B & -3.58 & $\mathrm{H}$ & 0.39 & B & -2.98 & $\mathrm{H}$ \\
\hline 47 & TMPI & 6.36 & $\mathrm{H}$ & -7.65 & $\mathrm{H}$ & -0.19 & B & 12.14 & B \\
\hline 48 & TRIL & 10.22 & $\mathrm{H}$ & -7.45 & $\mathrm{H}$ & -9.41 & B & 16.91 & B \\
\hline 49 & TURI & 10.22 & $\mathrm{H}$ & -7.45 & $\mathrm{H}$ & 0.94 & $\mathrm{H}$ & -51.79 & $\mathrm{H}$ \\
\hline 50 & UNTR & 2.19 & G & -3.23 & $\mathrm{H}$ & 0.85 & $\mathrm{H}$ & -38.32 & $\mathrm{H}$ \\
\hline 51 & WAPO & -1.23 & B & -0.93 & $\mathrm{H}$ & 0.48 & B & 43.44 & B \\
\hline 52 & WICO & -0.49 & B & -3.93 & $\mathrm{H}$ & 1.65 & $\mathrm{H}$ & -8.30 & $\mathrm{H}$ \\
\hline 53 & ASIA & 2.79 & $\mathrm{H}$ & -4.53 & $\mathrm{H}$ & -1.42 & B & -2.59 & $\mathrm{H}$ \\
\hline $\mathrm{H}=$ & Healt & & 15 & & 50 & & 24 & & 36 \\
\hline $\mathrm{G}=$ & Grey & & 17 & & 0 & & 0 & & 0 \\
\hline $\mathrm{B}=$ & $\begin{array}{l}\text { Bankrup } \\
\mathrm{t}\end{array}$ & & 21 & & 3 & & 29 & & 17 \\
\hline
\end{tabular}

The observations in table 2 above show that the Altman model predicts 15 companies not going bankrupt or at $28.30 \%, 17$ companies are in the gray area or $32.08 \%$ and 21 companies are in the bankrupt category or $39.62 \%$. Ohlson's model produces a prediction of 
50 companies in a non-bankrupt condition or at $94.34 \%$ and 3 bankrupt companies or at $5.67 \%$. The Springate Model produces predictions of 24 companies in a non-bankrupt condition or at $45.28 \%$ and 29 bankrupt companies or at $54.72 \%$. While the Zmijewski model yields predictions 36 non-bankrupt companies or $67.92 \%$ and 17 companies are bankrupt or $32.08 \%$. The prediction of the most bankrupt companies produced is by using the Springate model as many as 29 companies predicted to go bankrupt, then Altman as many as 21 companies are predicted to go bankrupt, Zmijewski as many as 17 companies are predicted to go bankrupt and the least prediction of bankruptcy is Ohlson as many as 3 companies. Simultaneously based on the Altman, Ohlson, Springate and Zmijewski models, only two companies are predicted to be bankrupt, namely PT Electronic City Indonesia Tbk (ECII) and PT Rimo International Lestari Tbk (RIMO).

\subsection{Descriptive Statistics}

The descriptive statistical results shown in Table 3 show that the minimum value of the Altman model is -57.81 which means the company has the worst and predicted in bankrupt conditions; the company is PT Renuka Coalindo Tbk. While the maximum value of the Altman model is 42.31 which shows that the company is in the healthiest condition and is predicted not to be bankrupt; the company is PT Nortcliff Citranusa Indonesia Tbk (SKYB). In contrast to the Altman model, in the Ohlson model, a minimum value of -7.86 indicates the healthiest and most predictable condition of a bankrupt company, the company is PT Nortcliff Citranusa Indonesia Tbk (SKYB) while a maximum value of 37.96 indicates the company's worst and predicted condition of bankruptcy, namely PT Electronic City Indonesia Tbk (ECII).

Just like the Altman model, the minimum value of -9.41 Springate model shows a bad company condition and is predicted to be bankrupt namely PT Triwira Insanlestari Tbk (TRIL). The maximum value of 26.81 Springate model shows that the company is in a very healthy condition and is predicted not to be bankrupt, the company is PT Nortcliff Citranusa Indonesia Tbk (SKYB). Similar to Ohlson's model, the minimum value of Zmijewski's model of -507.99 indicates the healthiest and most predictable condition of a bankrupt company, the company is PT Nortcliff Citranusa Indonesia Tbk (SKYB); while the maximum value of 710.84 indicates the company's worst and bankrupt condition, namely PT Global Teleshop Tbk (GLOB).

Tabel 3. Descriptive Statistics

Descriptive Statistics

\begin{tabular}{|l|r|r|r|r|r|}
\hline & $\mathrm{N}$ & \multicolumn{1}{|c|}{ Minimum } & Maximum & \multicolumn{1}{l|}{ Mean } & \multicolumn{1}{l|}{ td. Deviation } \\
\hline Altman & 53 & -57.81 & 42.31 & 2.0875 & 11.47554 \\
Ohlson & 53 & -7.86 & 37.96 & -1.9685 & 6.89476 \\
Springate & 53 & -9.41 & 26.81 & 1.1626 & 4.15243 \\
Zmijewski & 53 & -507.99 & 710.84 & -10.9245 & 144.26111 \\
Valid N (listwise) & 53 & & & & \\
\hline
\end{tabular}

\subsection{Multicollinearity Test}

Multicollinearity test is done by calculating Variance Inflation Factor (VIF). If the tolerance value $>0.10$ and the value of VIF $<10$, it can be concluded that there are no symptoms of multicollinearity (Ghozali, 2006). The results of the multicollinearity test are shown in Table 5. Based on the results of the multicollinearity test in table 5 it is shown that 
all independent variables have a tolerance value above 0.1 and the VIF value on all independent variables is far below the number 10, thus, it can be concluded that there is no independent correlation in this study.

Table 4. Multicollinearity Test

\begin{tabular}{|c|c|c|c|c|c|c|c|}
\hline & & B & S.E. & Wald & $d f$ & Sig. & $\operatorname{Exp}(B)$ \\
\hline Step $1^{a}$ & Altman & -.123 & .055 & 5.048 & 1 & .025 & .884 \\
\hline & Ohlson & .017 & .049 & .126 & 1 & .722 & 1.018 \\
\hline & Springate & -.925 & .310 & 8.870 & 1 & .003 & .397 \\
\hline & Zmijewski & -.001 & .003 & .156 & 1 & .692 & .999 \\
\hline
\end{tabular}

a. Dependent Variable: BankruptNonbankrupt

\subsection{Hosmer and Lemeshow Test Results}

Hosmer and Lemeshow test results show the probability value of the dependent variable; the test results shown in table 5 show a significant value of 0.996 greater than 0.05 , which means there is no difference between the predictions of the logistic regression model and the observational data. So it can be concluded that the data in this study are in accordance with the research model so that the regression model is feasible to predict non-bankrupt variables and testing can proceed.

Table 5. Hosmer and Lemeshow Test

\begin{tabular}{|l|l|l|l|}
\hline Step & Chi-square & Df & Sig. \\
\hline 1 & 1.222 & 8 & .996 \\
\hline
\end{tabular}

\subsection{Partial Test/Wald Test}

Partial logit regression test was carried out to determine the effect of each independent variable on the dependent variable. The level of significance of the independent variables in the study must be less than 0.05 on the dependent variable. Partial test results (Wald test) can be seen in Table 6 below:

Table 6. Partial Test (Wald Test)

\begin{tabular}{|ll|r|r|r|r|r|r|}
\hline & \multicolumn{1}{|c|}{ B } & S.E. & Wald & df & Sig. & Exp(B) \\
\hline Step 1a & Altman & -.123 & .055 & 5.048 & 1 & .025 & .884 \\
& Ohlson & .017 & .049 & .126 & 1 & .722 & 1.018 \\
& Springate & -.925 & .310 & 8.870 & 1 & .003 & .397 \\
& Zmijewski & -.001 & .003 & .156 & 1 & .692 & .999 \\
\hline
\end{tabular}

a. Variable(s) entered on step 1: Altman, Ohlson, Springate, Zmijewski.

Based on the partial test results in table 6 above, it is known that the Altman and Springate variables have a significant value below 0.05. This means that the Altman and Springate bankruptcy prediction model can be used to predict the bankruptcy of trading sector companies in Indonesia. The Springate model has better accuracy than the Altman model, because the significant value of the Springate model is 0.003 smaller than the 
significant value of the Altman model of 0.025. In contrast to the Altman and Springate models, Ohlson and Zmijewski's prediction models have a significantly greater value than 0.05, which means that Ohlson and Zmijewski's models cannot be used to predict bankruptcy of trade sector companies in Indonesia. The regression equation formed in partial testing is as follows:

$\mathrm{Y}=-0.123$ Altman +0.017 Ohlson -0.925 Springate $-0.001 \mathrm{Zmejewski}$

\subsection{Ommibus Test and Pseudo R-Square}

The results of the Omnibus Test and Pseudo R-Square or often called Nagelkerke R Square respectively shown in table 7 and table 8 .

Table 7. Omnibus Test

\begin{tabular}{|rl|r|r|r|}
\hline & & Chi-square & \multicolumn{1}{|l|}{ df } & Sig. \\
\hline Step 1 & Step & 18.563 & 4 & .001 \\
& Block & 18.563 & 4 & .001 \\
& Model & 18.563 & 4 & .001 \\
\hline
\end{tabular}

In table 7 above the significant value of the Omnibus Test of 0.001 is below 0.05 . If the significant value of the Omnibus is lower than 0.05, this means that there is a significant influence of the independent variables simultaneously affecting the dependent variable.

Table 8. Pseudo R-Square (Nagelkerke R-Square)

\begin{tabular}{|l|r|r|l|}
\multicolumn{5}{c|}{ Model Summary } \\
\hline & & \& Snell R & gelkerke R \\
Square & Square \\
Step & -2 Log likelihood & & \\
\hline 1 & $54.911^{\mathrm{a}}$ & .295 & .394 \\
\hline
\end{tabular}

a. Estimation terminated at iteration number 6 because parameter estimates changed by less than .001 .

Table 8 above shows the Nagelkerke R Square value of 0.394 or $39.4 \%$, this means that the independent variable can only explain the dependent variable by $39.4 \%$, while $60.6 \%$ is explained by other factors not contained in the model.

\section{Conclusion}

In this paper we examine the empirical performance of a number of bankruptcy prediction models. This model uses a variety of different econometric specifications such as the Altman discriminant multi-analysis (MDA) model, the Ohlson logit model, the Springate step MDA model, and the Zmijewski probit model. This bankruptcy prediction model offers various findings on the performance of trading sector companies in Indonesia during the observation period. The Springate model finds the largest number of companies in the bankrupt category, while the Ohlson model documents more companies in the nonbankruptcy category. When the bankruptcy prediction scores of each model are compared together based on the Altman, Ohlson, Springate and Zmijewski models, only two companies 
are predicted to be bankrupt, namely PT Electronic City Indonesia Tbk (ECII) and PT Rimo International Lestari Tbk (RIMO).

We also find that the Altman and Springate bankruptcy prediction model can be used to predict the bankruptcy of trading sector companies in Indonesia. The Springate model has better accuracy than the Altman model, because the significant value of the Springate model is 0.003 smaller than the significant value of the Altman model of 0.025 . Meanwhile, the Ohlson and Zmijewski prediction models cannot be used to predict the bankruptcy of trading sector companies in Indonesia. To provide more comprehensive findings, future studies on this issue are suggested to consider more companies from various industrial sectors to be used as research samples because various industrial sectors have different characteristics. In addition, future studies are also advised to use longer data periods so that they can provide a clearer picture of bankruptcy predictions.

\section{References}

Altman, E. I. (1968) 'Financial Ratios, Discriminant Analysis and The Prediction of Corporate Bankruptcy', The Journal of Finance, XXIII(4), pp. 589-609.

Altman, E. I. (1984) 'A Further Empirical Investigation of the Bankruptcy Cost Question', The Journal of Finance, XXXIX(4), pp. 1067-1089.

Aminian, A., Mosazade, H. and Khoshkho, O. I. (2016) 'Investigate the Ability of Bankruptcy Prediction Models of Altman and Springate and Zmijewski and Grover in Tehran Stock Exchange', Mediterranean Journal of Social Sciences, 7(4), pp. 208-214. doi: 10.5901/mjss.2016.v7n4s1p208.

Ashraf, S., Elisabete, G. S. F. and Serrasqueiro, Z. (2019) 'Do Traditional Financial Distress Prediction Models Predict the Early Warning Signs of Financial Distress ?', Journal of Risk and Financial Management, 12(55), pp. 1-17. doi: 10.3390/jrfm12020055.

Beaver, W. H. (1966) 'Financial Ratios as Predictors of Failure', Journal of Accounting Research, 4, pp. 71-111.

Ghozali, I. (2006) Aplikasi Analisis Multivariate dengan Program SPSS. Semarang, Indonesia: Badan Penerbit Universitas Diponegoro.

Marcinkevicius, R. and Kanapickiene, R. (2014) 'Bankruptcy Prediction in The Sector of Construction in Lithuania', in 19th International Scientific Conference; Economics and Management 2014, pp. 553-557. doi: 10.1016/j.sbspro.2014.11.239.

Nurcahyanti, W. (2015) STUDI KOMPARATIF MODEL Z-SCORE ALTMAN, SPRINGATE DAN ZMIJEWSKI DALAM MENGINDIKASIKAN KEBANGKRUTAN PERUSAHAAN YANG

TERDAFTAR DI BEI. (tidak dipublikasi) Program Studi Akuntansi, Fakultas Ekonomi. Universitas Negeri Padang.

Ohlson, J. A. (1980) 'Financial Ratios and The Probabilistic Prediction of Bankruptcy', Journal of Accounting Research, 18(1), pp. 109-131.

Pongsatat, S., Ramage, J. and Lawrence, H. (2004) 'Bankruptcy Prediction for Large and Small Firms in Asia: A Comparison of Ohlson and Altman', Journal of Accounting and Croporate

Governance, 1(2), pp. 1-13.

Springate, G. L. (1978) Predicting the Possibility of Failure in a Canadian firm. (Unpublished Thesis). Britisch Columbia, Canada: Simon Fraser University. 
Syamni, G., Majid, M. S. A. and Siregar, W. V. (2018) 'Bankruptcy Prediction Models and Stock Prices of the Coal Mining Industry in Indonesia', Etikonomi, 17(1), pp. 57-68.

Timmermans, M. and Finance, M. (2014) U . S . CORPORATE BANKRUPTCY PREDICTING

MODELS. Tilburg University.

Wu, Y., Gaunt, C. and Gray, S. (2010) 'Journal of Contemporary Accounting \& Economics A comparison of alternative bankruptcy prediction models', Journal of Contemporary Accounting \& Economics. Elsevier Ltd, 6(1), pp. 34-45. doi: 10.1016/j.jcae.2010.04.002.

$\mathrm{Xu}$, M. and Zhang, Æ. C. (2009) 'Bankruptcy prediction: the case of Japanese listed companies',

Springer Science + Business Media, 14, pp. 534-558. doi: 10.1007/s11142-008-9080-5.

Zmijewski, M. E. (1984) 'Methodological Issues Related to the Estimation of Financial Distress Prediction Models', Journal of Accounting Research, 22, pp. 59-82. 